\title{
TAUHIDIC PARADIGM SEBAGAI BASIS DALAM MEWUJUDKAN UMAT BERAGAMA YANG TOLERAN DAN MODERAT
}

\author{
Nuzul Fitriansyah \\ UIN Sunan Kalijaga Yogyakarta \\ fitriansyahnuzul30@gmail.com \\ Rachma Vina Tsurayya \\ UIN Sunan Kalijaga Yogyakarta \\ fitriansyahnuzul30@gmail.com
}

\begin{abstract}
;
The issue of religion and tolerance is always interesting to discuss if we know that someone should be more religious, then more tolerant of his attitude towards others. However, various facts that have occurred in the past few decades indicate that the average cases of intolerance are caused by some individuals who misunderstand the concept of religion even to monopolize a truth. The existence of these facts does not mean making religion a scapegoat that can make a person intolerant, more precisely this happens because of the misunderstanding when someone understands some of the concepts that exist in religion itself. One concept that is the core of any religion is the concept of divinity. In Islam the concept of divinity is known as Tawheed which teaches to disperse God. Some muffasir who take focus in the domain of Liberation Interpretation usually use this monotheistic paradigm as the basis of liberation, say for example Amina Wadud with the issue of rejection of patriarchal culture or Farid Essack who uses this paradigm in eradicating apartheid (discrimination against blacks) that occurs in Africa. Therefore in this case the author tries to offer the use of this monotheistic paradigm to minimize the level of intolerance that occurs due to the existence of miss understanding in understanding religious concepts, where the monotheistic paradigm directs that the true buman dignity is the same in the eyes of God so that such views are expected can suppress intolerance and monopoly on truth in the name of religion.

Keyword: Taubidic Paradigm, Tolerance, Intolerance, Peaceful
\end{abstract}

\begin{abstract}
Abstrak;
Isu agama dan toleransi selalu menarik untuk dibahas jika melihat seharusnya semakin beragama seseorang, maka semakin toleran sikapnya terhadap orang lain. Namun, berbagai fakta yang terjadi dalam beberapa dekade terakhir ini menunjukkan bahwa rata-rata kasus-kasus intoleransi disebabkan oleh beberapa oknum yang salah dalam memahami konsep beragama bahkan hingga memonopoli sebuah kebenaran. Adanya fakta-fakta tersebut bukan berarti menjadikan agama sebagai kambing hitam yang dapat membuat seseorang bersikap intoleran, lebih tepatnya hal tersebut terjadi karena adanya miss understanding ketika seseorang memahami beberapa konsep yang ada dalam agama itu sendiri. Salah satu konsep yang menjadi core dalam agama manapun ialah konsep ketuhanan. Dalam Islam konsep ketuhanan dikenal dengan Tauhid yang mengajarkan untuk mengesakan tuhan. Beberapa muffasir yang mengambil fokus dalam ranah Tafsir Pembebasan biasanya menggunakan paradigma tauhid ini sebagai basis pembebasan, sebut saja misalnya Amina Wadud dengan isu penolakan budaya patriarki atau Farid Essack yang menggunakan paradigma ini dalam memberantas apartheid (diskriminasi terhadap ras kulit hitam) yang terjadi di Afrika. Oleh karena itu dalam hal ini penulis mencoba menawarkan penggunaan paradigma tauhid ini untuk meminimalisir tingkat intoleransi yang terjadi akibat adanya miss understanding dalam memahami konsep-konsep keagamaan, dimana paradigma tauhid ini mengarahkan bahwa sejatinya martabat manusia sama di mata tuhan sehingga diharapkan dengan adanya pandangan seperti itu dapat menekan intoleransi dan monopoli kebenaran yang mengatasnamakan agama.
\end{abstract}

Kata Kunci: Tauhidic Paradigm, Toleransi, Intoleransi, Perdamaian. 



\section{Pendahuluan}

Hasil survey dan penelitian dari beberapa lembaga survey keagamaan menyatakan bahwa intoleransi baik dalam agama yang sama maupun berbeda selalu ada di setiap kurun waktu dalam satu tahun. Berdasarkan hasil Survey dari Setara Institute, sepanjang tahun 2018 terdapat 160 peristiwa pelanggaran kebebasan beragama/berkeyakinan (KBB) dengan 202 bentuk tindakan, yang tersebar di 25 provinsi. Intoleransi agama dewasa ini dianggap sebagai sebuah hal yang selalu terjadi di setiap tahunnya baik dalam lingkup national, internasional, intra agama, maupun antar agama. Setelah diteliti lebih dalam diketahui bahwa latar belakang yang menyebabkan terjadinya kasus-kasus tersebut sangat beragam, mulai dari politik, kepentingan kelompok hingga urusan ekonomi dan bisnis. ${ }^{1}$

Solusi untuk mengurangi kasus-kasus intoleransi tersebut juga sudah barang tentu diupayakan oleh berbagai pihak yang menginginkan terciptanya kedamaian dan sikap toleransi antar sesama umat beragama. Dalam tulisan ini penulis mencoa memberikan tawaran solusi dengan sebuah pandangan yang penulis sebut sebagai Taubidic Paradigm (paradigma tauhid). Tawbidic Paradigm atau paradigma tauhid ini merupakan paradigma yang digunakan oleh beberapa sarjana tafsir dalam upaya merespon dan memberi solusi terhadap berbagai persoalan keadilan, hak asasi, dan isu-isu kemanusiaan.

Secara singkat dapat dikatakan bahwa Tawhidic Paradigm ini memandang semua makhluk Tuhan dengan pandangan kesetaraan sehingga berimplikasi kepada anggapan bahwa yang paling tinggi adalah tuhan itu sendiri. Dengan menempatkan tuhan pada posisi paling tinggi membawa kepada konsekuensi bahwa seluruh makhluk tuhan setara. Kesetaraan ini sendiri nantinya akan mengantarkan kepada anggapan bahwa atas nama makhluk tuhan seluruhnya setara tidak ada perbedaan dan tidak ada yang merasa paling karena adanya fungsi dan peran masing-masing dalam menjalani kehidupan, apabila hal-hal ini dapat diterima dan dipahami dengan baik maka keragaman dan perbedaan bukanlah sebuah keniscahyaan. Pandangan seperti ini menurut penulis sangat relevan untuk ditawarkan dalam rangka menyelasaikan isu-isu intoleransi agama yang sebenarnya didasari karena ketidakinginan menerima perbedaan antar satu sama lain.

Ada beberapa alasan yang melandasi penggunaan paradigma tauhid ini dalam rangka meminimalisir intoleransi beragama sehingga dapat menciptakan masyarakat yang modern dan toleran. Pertama, Salah satu konsep yang menjadi core dalam agama manapun ialah konsep ketuhanan. Dalam Islam konsep ketuhanan dikenal dengan Tauhid yang mengajarkan untuk mengesakan tuhan. Kedua, melihat track record paradigma tauhid ini yang sudah seringkali dijadikan basis dasar dalam menyelesaikan problem-problem yang berkaitan langsung dengan ketidakadilan seperti rasisme, ketimpangan gender, dan isu-isu kemanusiaan. Sebut saja misalnya Amina Wadud seorang mufassir feminis yang menggunakan paradigma tauhid sebagai basis dalam tafsirnya untuk menumpas budaya patriarki, atau Farid Essack seorang mufassir dari Afrika yang menggunakan paradigma ini sebagai basis terhadap kasus apartheid. Ketiga, kasus-kasus intoleransi yang ada selama ini selalu saja mengatasnamakan agama sebagai latar belakang penyebab utama, padahal sejatinya agama manapun baik dalam konsep dan pengamalan selalu saja mengajak kepada pesan kedamaian dan menghargai sesama umat beragama. Oleh karena itu, paradigma

${ }^{1}$ Laporan Siaran Pers Setara Institute "Melawan Intoleransi di Tahun Politik; Kondisi Kebebasan Beragama/Berkeyakinan dan Pemajuan Toleransi di Indonesia Tahun 2018”, 7.

Volum 3, Nomor 1, Januari 2020| 51 
tauhid ini menurut penulis penting untuk dikaji sebagai salah satu konsep dalam agama dan bagaimana pengaruhnya terhadap kehidupan beragama yang lebih moderat dan toleran.

\section{Metode}

Penelitian ini adalah penelitian pustaka (library research) dengan objek penelitian berupa data pustaka. Penelitan ini menggunakan metode kualitatif yang merupakan penelitian interpretative yang di dalamnya peneliti terlibat dalam pengalaman yang berkelanjutan dan terus menerus dengan partisipan (data). Keterlibatan peneliti berperan untuk mengidentifikasi bias, nilai, dan latar belakang data. ${ }^{2}$ Alasan penggunaan model penelitian kualitatif ini ialah untuk mendapatkan lebih banyak jawaban dari rumusan masalah. Dalam penelitian ini, terdapat dua sumber yang digunakan yaitu sumber primer dan sumber sekunder. Data di penelitian ini didapatkan dari pengumpulan sumber-sumber primer kemudian sumber sekunder untuk selanjutnya dilakukan penelitian tentangnya.

Adapun sumber primer dari penelitian ini adalah kasus yang telah terjadi tentang Intolernasi beragama serta survey dari beberapa lembaga survey dan juga referensi-referensi yang berkaitan langsung dengan persoalan Tawhidic Paradigm seperti pandangan Amina Wadud dalam karyanya Qur'an and Women, Farid Essack dalam karyanya The Qur'an as a User Guide, dan Abdurrahman Wahid dalam Prisma Pemikiran Gus Dur serta beberapa referensi lainnya. Sedangkan, sumber sekunder dari penelitian ini adalah buku acuan (referensi) yang menunjang penelitian ini termasuk karya tulis yang berupa jurnal atau artikel ilmiah yang telah membahas tentang tema Intolernasi Agama.

Sejauh penelusuran penulis, sudah cukup banyak penelitian yang membahas tentang isu intoleransi beragama dan upaya pencegahannya. Namun, belum banyak penelitian yang secara langsung menggunakan paradigma tawhdic paradigm sebagai salah satu upaya pencegahan intoleransi tersebut kecuali hanya dalam jumlah yang sedikit. Setelah penulis teliti setidaknya terdapat beberapa karya ilmiah yang menggunakan paradigma ini misalnya, Tawhidic Paradigm on Organizational Policy and Startegy karya Suhaimi Mhd Sarif dan A Contemporary Theory of Social Enterpreneurship from Tawhidic Paradigm: A Conceptual Study yang ditulis oleh Zaliza Azan dan Suhaimi Mhd Sarif. Berdasarkan penelusuran tersebut, penulis menganggap perlu untuk melakukan riset ini dan mencoba menawarkan teori Tawhidic Paradigm dalam rangka memberi solusi-solusi terhadap penyelesaian peoblem intoleransi agama.

\section{Gambaran Umum Tauhidic Paradigm}

\section{Definisi Tauhid}

Tauhid merupakan salah satu cabang ilmu yang sangat inti dalam Islam. Hal ini dikarenakan pembahasan yang ada di dalam ilmu tauhid membahas mengenai konsep ketuhanan yang merupakan konsep inti dalam pemahaman seluruh umat beragama manapun. Istilah tauhid sendiri berasal dari bahasa arab yang merupakan masdar dari kata Wabhada, Yuwabbidu, Taubidan yang secara etimologis, tauhid memiliki arti keesaan, maksudnya ialah yaki bahwa Allah Swt

${ }^{2}$ Jhon. W. Crashwell, Research Design.terj. Achmad Fawaid dan Rianayati Kusmini P, (Yogyakarta: Pustaka Pelajar.2016), 264

52 | Nuzul Firiansyah \& Rachma Vina Tsurayya - Tauhid Paradigm Sebagai Basis,.. 
adalah esa, tunggal, dan satu. Sejalan dengan pengertian tersebut, dalam hal ini tauhid menekankan bahwa Allah adalah tunggal baik dalam dzat, sifat, maupun perbuatannya. ${ }^{3}$

Beberapa ahli juga memberikan definisi mengenai cabang ilmu ini, misalnya definisi yang datang dari Zainudin Sardar yang mengatakan bahwa ilmu tauhid merupakan

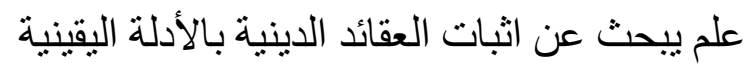

Ilmu yang membahas segala kepercayaan keagamaan dengan menggunakan dalil-dalil yang meyakinkan

Definisi lain datang dari Muhammad Abduh yang mendefinisikan ilmu tauhid adalah ilmu yang membahas wujud Allah, yakni meliputi sifat yang wajib tetap pada-Nya, sifat yang boleh disifatkan kepada-Nya. Selain itu Abduh juga berargumen bahwa ilmu ini juga mengkaji tentang rasul Allah, yakni terkait dengan keyakinan akan kerasulan mereka. ${ }^{4}$

Definisi lainnya yaitu yang diutarakan Al-Farabi yang mendefinisikan ilmu tauhid sebagai kemampuan yang dimiliki seseorang untuk membela pandangan-pandangan dan perbuatanperbuatan yang secara tegas disampaikan oleh Rasulullah, dan membantah apapun yang menyelisihinya. ${ }^{5}$

Dalam perkembangannya sebagai sebuah diskursus ilmu, tauhid juga mengalami perkembangan salah satunya dari segi klasifikasinya. Dalam hal ini setidaknya ada 3 macam klasifikasi tauhid, yaitu:

Pertama. Taubid Rububiyah, adalah keyakinan seorang mukmin bahwa alam semesta ini diciptakan oleh Allah Swt, dan senantiasa menadapatkan pengawasan dan pemeliharaan dari pada-Nya. ${ }^{6}$

Kedua. Taubid Ulubiyah, tauhid ini muncul karena adanya tauhid rububiyah, yaitu sikap konsistensi seorang mukmin bahwa segala pujian, doa, dan harapan, amal dan perbuatannya hanyalah semata untuk mengabdi dan berbakti kepada Allah.

Ketiga. Taubid Asma wa Sifat, yaitu menetapkan nama-nama dan sifat-sifat yang sudah ditetapkan Allah untuk diri-Nya melalui lisan Rasul-Nya dengan cara yang sesuai kebesaran-Nya. Serta menolak atau menafikan semua sifat yang dinafikan Allah terhadap diri-Nya, baik melalui kitab sucinya al-Quran atau melalui sunnah Rasul-Nya. ${ }^{7}$

Dari beberapa pengertian tauhid di atas dapat kita ketahui bahwa sejatinya tauhid adalah soal pemahaman yang sangat dasar dalam Islam, karena pembahasan yang ada dalam cabang ilmu ini bersinggungan langsung dengan sifat-sifat tuhan yang muaranya mengarah kepada bagaimana cara seseorang mengesakan tuhan dari segala sisi baik dzat, sifat, maupun perbuatannya. Namun yang menjadi pertanyaan selanjutnya yaitu bagaimana kemudian tauhid yang kita pahami secara

${ }^{3}$ Zainuddin, Imu Taubid Lengkeap, (Jakarta: Rineka Cipta, 1996), 1.

${ }^{4}$ Muhammad Abduh, Risalab Taubid, (Jakarta: Bulan Bintang, 1992), 33.

${ }^{5}$ Sahilun A. Nasir, Pemikiran Kalam (Teologi Islam) Sejarah Agama dan Perkembangannya, (Jakarta: PT. Raja Grafindo Persada), 2012, 1.

${ }^{6}$ Ghozali Munir, Tauhid Sejarah dan Implementasi, (Semarang: Rasail Media Grup, 2013), 14.

${ }^{7}$ Ghozali Munir, Taubid Sejarah dan Implementasi, (Semarang: Rasail Media Grup, 2013), 16 
teoritis seperti penjelasan di atas dapat menjelma sebagai spirit dan basis yang mengarah kepada keadilan yang dapat membangun dan mengubah pola pikir sehingga pemahaman tentang tuhan ini tidak hanya untuk tuhan. Namun juga dapat membumi menjadi sebuah cabang ilmu yang bersifat praksis dan dapat menjawab persoalan realitas yang berkembang. Terkait dengan wacana di atas selanjutnya kita akan melihat perkembangan tauhid sebagai sebuah cabang ilmu menurut para ahli mulai dari klasik hingga kontemporer.

\section{Dari Tauhid Teosentris ke Tauhid Antroposentris}

Memasuki era modern kontemporer, tauhid mengalami perkembangan-perkembangan baik secara teoritis dan bahkan hingga menyentuh hingga ke ranah praksis, salah satu wacana yang muncul ialah gagasan mengenai perkembangan dari tauhid yang bersifat teosentris kepada tauhid yang bersifat antroposentris sebagaimana yang ditawarkan oleh beberapa tokoh-tokoh cendekiawan seperti Hassan Hanafi, Ismail Raji al-Faruqi, Nurcholis Majid dan lain semisalnya. Wacana-wacana seperti ini juga muncul sebagai sebuah upaya untuk membumikan tauhid menuju ranah praksis yang dapat bersentuhan langsung dengan fenomena dan realitas yang terjadi dalam kehidupan manusia. ${ }^{8}$

Untuk memahami hal tersebut tentunya terlebih dahulu kita harus memahami kedua istilah yang muncul pada sub bab ini yaitu teosentrisme dan antroposentrisme. Teosentrisme berasal dari bahasa Yunani theos yang memiliki arti tuhan dan bahasa Inggris center yang berarti pusat. Teosentrisme mengacu pada pandangan bahwa sistem keyakinan dan nilai terkait ketuhanan secara moralitas lebih tinggi dibandingkan sistem lainnya, jelasnya teosentrisme disini menkankna bahwa tuhan sebagai pusat dari alam semesta.

Sedangkan antroposentrime merupakan kebalikan dari teosentrisme, bila teosentrisme menekankan bahwa tuhan sebagai pusat alam semesta, maka antrposentrime menempatkan bahwa manusia merupakan pusat dan tujuan akhir dari alam semesta. Hal ini mengacu kepada pandangan bahwa nilai-nilai kemanusiaan merupakan pusat untuk berfungsinya alam semesta. Pemahaman antroposentris ini sangat jelas mengisyaratkan bahwa manusia mempunyai kebebasan dalam melakukan perbuatannya tanpa campur tangan tuhan. Hal ini bisa dilihat bahwa nilai-nilai kemanusiaan lebih tinggi dibandingkan dengan ketuhanan.

Masyarakat Arab sebelum Islam dipengaruhi oleh paham jabariyah yang pada waktu itu bersifat serba sederhana dan jauh dari pengetahuan, terpaksa menyesuaikan hidup mereka dengan suasana padang pasir, dengan panasnya yang terik serta tanah dan gunungnya gundul. Dengan kondisi yang demikian, mereka tidak banyak melihat jalan sekeliling mereka sesuai dengan keinginan mereka sendiri. Mereka merasa dirinya lemah dan tak berkuasa dalam menghadapi kesukaran-kesukaran hidup yang ditimbulkan suasana padang pasir. Kehidupan sehari-hari mereka banyak tergantung pada kehendak nature (alam). Hal ini membawa mereka pada sikap fatalistis. Ketika paham qodariyah dibawa ke dalam kalangan mereka oleh orang-orang Islam yang

\footnotetext{
${ }^{8}$ Azyumardi Azra, Hassan Hanafi dari Akidah ke Revolusi Sikap Kita Terbadap Tradisi Lama,
} (Jakarta: Paramadina, 2003), 9-11.

${ }^{9}$ Aksin Wijaya, Dari Membela Tuhan ke Membela Manusia, (Bandung: Mizan, 2018), 152. 
bukan berasal dari Arab padang pasir, hal ini menimbulkan kegoncangan dalam pemikiran mereka. Paham qodariyah ini mereka anggap bertentangan dengan ajaran Islam. ${ }^{10}$

Selain kedua kelompok tersebut, ada aliran maturidiyah yang juga dikelompokkan kepada kelompok yang memiliki kesamaan dengan paham qodariyah. Sebab, mereka dianggap menggunakan kebebasan akal secara berlebihan. Sementara itu kelompok yang ketiga berada di tengah-tengah. Mereka mencoba memadukan keduanya yaitu antara paham jabariyah dan qodariyah. Kelompok ini diwakili oleh aliran Asy'ariyah yang dikembangkan di Irak oleh Ali bin Ismail bin Salim bin Isma'il bin Abu Musa Al Asy'ari pada tahun 873-935 M. Aliran Asy'ariyah cenderung menyerahkan peranan ketetapan takdir itu kepada Allah. Sehingga ada yang menyebut aliran Asy'ariyah ini tak lebih sebagai cabang aliran Jabbariyah. Namun, di sisi lain juga meberikan kebebasan kepada manusia untuk memilih perbuatan yang ingin dilakukan. ${ }^{11}$

Memasuki abad pertengahan manusia dibebaskan dari ketakutan kepada dewa-dewa yang merupakan paham mitologi, dan hanya tunduk kepada tuhan dan kitab suci, artinya manusia kembali terpasung, kali ini oleh tuhan dan kitab suci. Manusia harus percaya otoritas tuhan dan kitab suci peradaban bersifat teosentris. ${ }^{12}$

Tetapi rupaya pandangan semacam ini semakin ditinggalkan ketika muncul pemikiran bahwa manusia adalah pusat segala sesuatu. Pandangan antroposentrisme muncul sebagai pendobrak pandangan teosentris secara revolusioner. Pandangan antroposentrisme atau humanisme, beranggapan bahwa kehidupan tidak berpusat pada tuhan, tetapi pada manusia. Dalam hal ini manusia yang menjadi penguasa realitas, oleh karena itu manusialah yang menentukan nasibnya sendiri, bukan tuhan. Manusia bahkan dianggap sebagai penentu kebenaran. Itu sebabnya dewadewa dan kitab suci tidak diperlukan lagi. ${ }^{13}$

Ajaran tauhid bukan hanya seputar penolakan terhadap kemusyrikan yang berbentuk berhala atau kepercayaan-kepercayaan yang mengingkari keesaan Tuhan. Tauhid juga bermakna bersatunya umat manusia yang bernaung di bawah keadilan. Karena hanya dengan keadilanlah maka nila-niai ketuhanan dapat terealisir, yang diinginkan oleh Hassan Hanafi adalah pengalihan perhatian dalam bangunan epistemology dalam pemahaman tauhid. Pada awalnya perhatian tersebut dipusatkan pada pembahasan mengenai Tuhan, pembahasan mengenai langit, atau melayani penguasa dengan melakukan rekontruksi pusat perhatian keilmuan ditujukan untuk membangun manusia, membela rakyat, memperhatikan bumi, dan menuju revolusi. ${ }^{14}$

Tauhid dalam Islam adalah tauhid yang membumi. Artinya, Islam harus sanggup menjawab tantangan, dinamika dan problematika kehidupan manusia seluruhnya, seperti ketika keadaan umat masih diliputi penjajahan, ketakutan, kemiskinan, ketimpangan, intimidasi, konservatisme,

\footnotetext{
${ }^{10}$ Harun Nasution, Teologi Islam Aliran-Aliran Sejarah Analisa Perbandingan, (Jakarta: UI Press.1986), 31-32.

${ }^{11}$ Agus Mustofa, Mengubab Takdir Serial ke-7 Diskusi Tasawnf Modern, (Surabaya: PADMA Press,2008), 70-71.

${ }^{12}$ Kuntowijoyo, Islam Sebagai Ilmu Epistemologi, Metodologi, dan Etika, (Yogyakarta: Tiara Wacana, 2006), 113.

${ }^{13}$ Kuntowijoyo, Islam Sebagai Ilmu Epistemologi, Metodologi, dan Etika, (Yogyakarta: Tiara Wacana, 2006), 114.

${ }^{14}$ Hassan Hanafi, Dari Aqidah ke Revolusi, terj. Asep Usman Ismail (dkk), (Jakarta: Paramadina, 2003), 14.
} 
westernisasi (perambatan), kebodohan, kehilangan rasa percaya diri dan kreativitas, perpecahan dan masalah lainnya. Ketika umat berada pada kondisi seperti ini, maka kita dituntut untuk menjadikan masalah-masalah tersebut sebagai tema ilmu Ushuluddin. Sikap tersebut dengan sendirinya mengharuskan adanya rekontruksi ilmu tauhid pola lama menjadi tauhid modern yang berhadapan langsung dengan realitas umat. ${ }^{15}$

Teologi teosentris seperti ini, sekalipun menurut Nurcholish Madjid, menghasilkan dampak positif (seperti adanya pegangan hidup), akan tetapi sesungguhnya ia memiliki efek samping yang sangat berbahaya, yaitu pembelengguan pribadi dan pemrosotan harkat martabat kemanusiaan. Adapun pergeseran teologi yang dimaksud adalah paradigma antroposentris, sebuah teologi yang menempatkan manusia sebagai pusat orientasinya (teologi yang mempunyai pandangan inti memanusiakan dan menyejaterakan manusia).

Teologi antroposentris yang dimaksud di sini jelas tentu saja bukan teologi antroposentris sekuleris sebagaimana yang dianut oleh orang-orang barat, dimana manusia sebagai pusat segalanya, manusia sebagai raja yang sah untuk mengeksploitasi seluruh kekayaan alam berdasarkan untung rugi bagi kepentingannya. Akan tetapi yang menjadi tujuan ialah antroposentris yan bersifat dialogis.

Tanpa disadari pandangan hidup teosentris dapat dilihat mewujudkan diri dalam kegiatan keseharian yang bersifat antroposentris, seseorang yang berketuhanan dengan sendirinya juga berperikemanusiaan. Hal ini terjadi karena sebenarnya ajaran ketuhanan ialah mengajarkan bagaimana memanusiakan manusia yang sama-sama merupakan makhluk tuhan. Jadi, sebenarnya teologi antroposentris bukan mengubah doktrin sentral tentang ketuhanan (tauhid), tetapi suatu upaya revitalisasi dan reaktualisasi pemahaman keagamaan, baik secara individual maupun kolektif dalam kenyataan-kenyataan empiris menurut perspektif ketuhanan. ${ }^{16}$

\section{Paradigma Tauhid Sebagai Metode}

Jika kita mencoba melihat fakta yang ada, penggunaan paradigma tauhid sebagai basis untuk menyentuh realitas dan problematika yang terjadi di masyarakat bukan merupakan hal yang sama sekali baru. Paradigma ini sudah digunakan oleh beberapa cendikiawan dan para sarjana muslim dalam beberapa dekade terakhir ini. Isu-isu yang dibahas juga mengarah kepada persoalan-persoalan yang berkaitan langsung dengan ketimpangan-ketimpangan, diskriminasi, buman rights dan lain sebagainya. Dalam sub bab ini penulis memberikan gambaran terkait dengan bagaimana paradigma tauhid ini bekerja. Untuk melihat hal tersebut, penulis menghadirkan beberapa tokoh yang menggunakan paradigma ini sebagai basis dasar pemikiran mereka. Tokohtokoh tersebut antara lain ialah sebagai berikut.

${ }^{15}$ Abad Badruzman, Kiri Islam Hassan Hanafi Menggugat Kemapanan Agama dan Politik, (Yogyakarta: Tiara Wacana, 2005), 8.

${ }^{16}$ Munawir, 'Fenomena Bencana Dalam Al-Qur'an Perspektif Pergeseran Teologi dari Teosentris ke Antroposentris”, Jurnal maghza, 2016. Institut Agama Islam Negeri Purwokerto.

56 | Nuzul Firiansyah \& Rachma Vina Tsurayya - Tauhid Paradigm Sebagai Basis,.. 
Amina Wadud

Amina Wadud, seorang sarjana studi al-Qur'an dari benua Amerika menyatakan pendapatnya terhadap persoalan-persoalan sensitif mengenai kesetaraan gender secara masif. Ia mengekspresikan pendapatnya melalui dua bukunya Qur'an and Women dan Inside the Gender: Jihad. Dalam bukunya tersebut ia memulai kajiannya dengan pembahasan mengenai penciptaan manusia yang terbentuk dari air mani (nutfab) berlaku dalam jenis kelamin perempuan ataupun lelaki. Ia juga menyinggung tentang perintah Tuhan jika perbuatan baik akan dinilai dan dicatat oleh Tuhan, baik dilakukan oleh lelaki maupun perempuan. Amina merupakan tokoh studi Qur'an pertama yang menggunakan paradigma tauhid dalam diskursus gender. Ia juga mencoba mengaplikasikannya dalam beberapa ayat, seperti ayat tentang poligami dan khulu' serta menuliskan pandangannya tentang kewajiban perempuan dalam lingkup patriarki sosial, seperti merawat anak. Pemikirannya menitikberatkan pada perlakuan yang adil dan setara bagi setiap makhluk Tuhan (khususnya perempuan) yang seluruhnya memiliki derajat yang sama dan tidak ada yang dilebihkan atau diistimewakan atas dasar pemikiran Tauhid, dimana hanya Tuhan yang boleh disembah dan dijunjung tinggi kuasa-Nya. ${ }^{17}$

Farid Essack

Farid Essack memiliki gagasan tentang teologi pembebasan. Gagasan ini ia tujukan sebagai pembelaan terhadap kaum marjinal yang dalam hal ini adalah kaum ras hitam di Afrika Selatan. Teologi pembebasan disini memiliki perbedaan dengan teologi tradisional dan teologi modern. Jika, teologi tradisional terfokus pada pengaplikasian ajaran-ajaran tradisional dalam bentuk ritual ibadah dan teologi modern terfokus pada pembaruan-pembaruan keislaman, maka teologi pembebasan disini memberi perhatian khusus kepada kaum-kaum marjinal. Farid Essack membuat sebuah retorika pembebasan al-Qur'an pada suatu teori teologis dan pluralism hermeneutika yang lebih koheren. Ia memfokuskan pada implikasi karakter politis dan teologis beberapaa kata kunci hermenutika dalam sebuah kawasan masyarakat yang menerima ketidakadilan, perpecahan, dan eksploitasi. Kata kunci tersebut adalah takwa, taubid, al-nas (manusia), al-mustadh'afina fi al-ardh (yang tertindas di dunia), al-'adl dan qisth (keseimbangan dan keadilan), serta jihad (perjuangan dan praksis). ${ }^{18}$ Sumbangan pemikirannya tentang teologi pembebasan dalam hal ini merupakan sebuah harta karun yang membuka pandangan baru dari alQur'an terhadap isu-isu politk-sosial masyarakat. Kaum-kaum marjinal yang ia contohkan dengan kaum berkulit hitam di Afrika, menjadi memiliki hak untuk dianggap dan diperhatikan.

\section{Abdurrahman Wahid}

Seorang bapak pluralisme Indonesia yang juga seorang cendekiawan dan Kiai karismatik, KH. Abdurrahman Wahid. Beliau merupakan salah seorang kiai dengan kesadaran toleransi yang tinggi, pemikirannya tidak terbatas pada lingkaran kitab-kitab kuning klasik saja, tetapi melampaui hingga ke berbagai cakrawala keilmuan dunia. Gus Dur memiliki nilai-nilai yang menjadi ciri khas dari pemikirannya tersebut, salah satunya adalah nilai ketauhidan. Ketauhidan disini bersumber dari keimanan kepada Allah yang didapat dengan cara penyaksian dan pengakuan jika Allah

${ }^{17}$ Amina Wadud. Qur'an and Woman: Rereading the Sacred Text from a Woman's Perspective, (New York: Oxford University Press,1999), 25.

${ }^{18}$ Farid Esack, al-Qur'an, Pluralism and Liberation: An Islamic Perspective of Interreligious Solidarity Against Opression, (New York: Oneworld,1996), 28. 
adalah sumber segala-galanya. Paradigma Tauhid tersebut menjadi referensi dan sumber berlakunya nilai-nilai yang diperjuangkan Gus Dur dalam berbagai bidang serta diwujudkan dalam perjuangan sosial, politik, ekonomi, kebudayaan dalam mengeakkan nilai-nilai kemanusiaan, termasuk keadilan dan perdamaian dunia. ${ }^{19}$

Dari beberapa pemikiran tokoh diatas, dapat kita simpulkan bahwa setidaknya paradigma tauhid ini telah berhasil digunakan dalam rangka menyelesaikan kasus-kasus tertentu seperti diskriminasi, ketimpangan gender dan bahkan lebih jauh lagi berbicara soal kemanusiaan. Oleh karena itu, bertolak belakang dari beberapa pemikiran tokoh tersebut lebih lanjut penulis mengharapkan agar paradigma tauhid ini terus berkembang dan menyentuh isu-isu lain. Sebagiamana yang akan penulis lakukan dalam tulisan ini. Kajian-kajian yang dilakukan oleh beberapa tokoh tersebut juga setidaknya menjadi titik pijak terutama mengenai bagaimana paradigma tauhid ini bekerja sebagai sebuah konsep dan metode.

\section{Studi Kasus Intoleransi Beragama}

Beragama secara aman, tidak terganggu, dan mendapatkan perlakuan sesuai dengan haknya merupakan hak setiap warga Negara. Kebebasan beragama berarti bebas untuk memilih agama atau menentukan agama yang dipeluk, serta kebebasan untuk melaksanakan ibadah menurut agama dan keyakinan masing-masing ${ }^{20}$. Konvenan Internasional Hak Sipil dan Politik (KHSP) 1996 yang telah diratifikasi Indonesia pada 23 Februari 2006, pasal pada 18 ayat 1 juga mengaminkan pendapat tersebut dalam pernyataannya "Setiap orang mempunyai hak atas kebebasan berpikir, berkeyakinan dan beragama. Hak tersebut mencakup kebebasan untuk mengetahui, menetapkan agama atau kepercayaan atas pilihannya sendiri dan kebebasan baik secara individu maupun bersama-sama dengan orang lain, baik di tempat umum maupun tertutup, untuk menjalankan agama atu kepercayaannya dalam kegiatan ibadah, ketaatan, pengenalan, dan pengajaran" 21 .

Dalam Islam, kebebasan beragama juga diberikan tempat oleh Allah dan Rasulnya. Hal itu dapat dilihat dari QS. Al-Baqarah: 256 Tidak ada paksaan dalam (menganut) agama (Islam), sesunggubnya telah jelas (perbedaan) antara jalan yang benar dengan jalan yang sesat dan QS. Al-Kafirun: 6 Untukmu agamamu, dan untukeku agamaku ${ }^{22}$. Kedua ayat tersebut ditafsirkan oleh Kiai Shaleh Darat dalam Tafsir Marah Labid ${ }^{23}$ dan At-Thobari ${ }^{24}$ dalam karya tafsirnya bahwa ayat tersebut ayat yang tidak memberlakukan pemaksaan dalam hal agama dan beribadah kepada Tuhan. Abdurrahman Wahid juga menafsirkan QS. Al-Baqarah: 256 sebagai ayat yang memerintahkan untuk saling

${ }^{19} 9$ Nilai Utama Gus Dur dalam bttps:// wmw.gusdurian.net/ diakses pada 15 Agustus 2019.

${ }^{20}$ Siti Musdah Mulia, "Menuju Kebebasan Beragama di Indonesia" dalam Hakim, ed. Bayang-bayang Fanatisme: Esai-esai untuk mengenang Nur Cholish, 228.

${ }^{21}$ Resolusi Majlis Umum Ratifikasi dan Aksesi Konvenan Internasional Hak-hak Sipil dan Politik, 10. Diakses dari Lembaga Studi dan Advokasi Masyarakat dalam bttps://referensi.elsam.or.id/2014/09/konvenan-internasional-bak-bak-sipil-dan-politik// pada 14 Agustus 2019

${ }^{22}$ Kementrian Agama Republik Indonesia. Al-Qur'an dan Terjemahnya. (Kudus: Menara Kudus, 2010), 44 dan 113.

${ }^{23}$ An-Nawawi, Tafsir Marah Labid, (Beirut: Dar al-Kitab al-Ilmiyyah, 2016)

${ }^{24}$ At-Thobari. Jami' al-Bayan fi Ta'wil al-Qur'an. (Beirut: Dar Ar-Risalah, 2016)

58 | Nuzul Firiansyah \& Rachma Vina Tsurayya - Tauhid Paradigm Sebagai Basis,.. 
menghormati, tidak ada peranan sedikitpun dari manusia untuk menentukan benar atau salahnya sebuah agama. Setiap agama berhak hidup di setiap tempat, termasuk Indonesia walaupun terdapat pemberlakuan yang berbeda perihal keberagamaan di berbagai dunia. ${ }^{25}$

Namun, terlepas dari hal tersebut, setiap makhluk Tuhan pasti memiliki hak untuk beribadah dan hidup dengan baik, layak dan nyaman. Hal yang sangat disayangkan adalah tidak semua pemeluk agama setuju dan paham mengenai pernyataan tersebut dan menganggap agama yang berbeda perlu dimusnahkan yang memunculkan berbagai usaha untuk merusak tatanan suatu agama. Di samping kasus-kasus di atas juga terdapat keputusan press dari beberapa lembaga survey yang meneliti berbagai kasus tentang toleransi.

Setara Institute, Sepanjang tahun 2018 terdapat 160 peristiwa pelanggaran kebebasan beragama/berkeyakinan (KBB) dengan 202 bentuk tindakan, yang tersebar di 25 provinsi. Intoleransi dalam beragama semakin bertambahnya tahun semakin meningkat. Intoleransi agama dewasa ini dianggap sebagai sebuah hal yang selalu terjadi di setiap tahunnya baik dalam lingkup nasional, internasional, intra agama, maupun antar agama. Banyak hal yang melatarbelakangi adanya kasus-kasus tersebut mulai dari politik, kepentingan kelompok hingga urusan ekonomi dan bisnis ${ }^{26}$. Sementara itu The Wahid Institute sebagaimana telah disebutkan di atas juga berhasil merekam peristiwa pelanggaran KBB pada 2017 sebanyak 213 peristiwa dengan 265 tindakan, angka peristiwa pada tahun 2017 ini naik bila dibandingkan dengan 2016 (204 peristiwa). Namun, jumlah tindakan turun dari jumlah tindakan tahun 2016 yang berjumlah 313 tindakan. ${ }^{27}$

Berikut ini akan kami paparkan kasus-kasus intoleransi beragama di Indonesia dan di Dunia. Intoleransi tersebut berada dalam lingkup satu agama maupun antar agama.

1. Pengusiran warga beragama minoritas di Bantul

Slamet Jurniarto, seorang penganut Katolik di Dusun Karet, Pleret, Bantul, Daerah Istimewa Yogyakarta diusir oleh warga setempat yang mayoritas penganut Muslim. Alasan yang dikemukakan warga adalah terdapat kesepakatan dari warga setempat mengenai hal tersebut.

"Kepala Dukuh Karet, Iswanto mengaku mengetahui keberadaan aturan itu telah berlaku sejak tahun 2015, belakangan ia membatalkan kesepakatan itu karena seorang warga bernama Slamet Jurniarto yang beragama Katolik mempersoalkan peratutan tersebut. Slamet tak diizinkan warga Karet menetap di dusun itu karena tak memeluk Islam. "Peraturan yang dulu dibuat, karena permasalahan ini, sudah ditarik dan dibekukan mulai hari ini," kata Iswanto seperti dilaporkan wartawan di Yogyakarta, Furqon Ulya Himawan. "Karena melanggar undang-undang dasar, kami sepakat mencabut. Dulu aturan ini dibuat bersama-sama, sekitar 30 orang dari tokoh agama dan perwakilan warga," kata Iswanto." 28

2. Pameran Seni Wiji Thukul Dibubarkan

${ }^{25}$ Abdurrahman Wahid, "Tafsir Surat Al-Baqarah:256 tentang Saling Menghormati” dalam https://islami.co/ diakses pada 15 Agustus 2019

${ }^{26}$ Diakses dari Siaran Pers Setara Institute, "Melawan Intoleransi di Tahun Politik; Kondisi Kebebasan Beragama/Berkeyakinan dan Pemajuan Toleransi di Indonesia Tahun 2018", 7.

${ }^{27}$ The Wahid Foundation, Laporan Tabunan Kemerdekaan Beragama/Berkeyakinan (KBB) di Indonesia 2017 (Jakarta: Wahid Foundation, 2018), 31.

${ }^{28}$ Diakses dari https:// www.bbc.com/indonesia/indonesia-47801818 pada 12 Agustus 2019. 
"Pameran Seni karya seniman Andreas Iswinarto yang menampilkan puisi Wiji Thukul, aktivis buruh dibubarkan oleh massa ormas setempat pada awal Mei 2017. Saat panitia sedang melakukan persiapan dan memajang beberapa karya seni, puluhan anggota ormas datang ke lokasi pameran di Kantor Pusat Studi Hak Asasi Manusia Universitas Islam Indonesia, Bantul. Mereka pun meminta agar pameran dibatalkan. Tak hanya itu, anggota ormas juga mengambil paksa 5 karya dan beberapa lembar puisi Wiji Thukul. Padahal, pameran ini digelar bertujuan untuk mempelajari tokoh Wiji Thukul sebagai rangkaian peringatan 19 tahun reformasi dan hilangnya Wiji Thukul. Pameran ini juga bagian dari rangkaian acara kebebasan pers." 29

\section{Persekusi terhadap Biksu Mulyanto Nurhalim}

Biksu Mulyanto Halim dan pengikutnya pada 9-10 Februari 2018 digrebek oleh sekelompok warga Desa Caringin, Kecamatan Legok, Kabupaten Tangerang, Banten. Mereka menggrebeknya dengan alasan sang Biksu sering mengadakan kegiatan ibadah di kediamannya hingga mengajak warga sekitar untuk berpindah agama. Adanya penggrebekan tersebut membuat Biksu Mulyanto membuat surat pernyataan sangkalan tuduhan tersebut dan berpindah kediaman dari Desa Caringin. Namun, terdapat fakta lain yang ditemukan bahwa petinggi di Desa tersebut tidak mengiyakan adanya intoleransi dengan agama non-Muslim, menurut mereka justru sangat toleran kepada para pemeluk agama selain Islam. ${ }^{30}$

\section{Serangan kepada dua Tokoh Islam}

Pada akhir Januari dan awal Februari 2018, satu tokoh agama di Jawa Barat wafat akibat diserang dan satu tokoh dianiaya oleh oknum yang tidak dikenal. Kedua tokoh tersebut adalah Pimpinan Pusat Persatuan Islam (PERSIS) HR Prawoto, dan Tokoh NU Jawa Barat, KH. Umar Basri. ${ }^{31}$

5. Bom Bunuh diri di Chad Afrika

Pada 14 Agustus 2019 di sekitar Chad Afrika, bom bunuh diri diledakkan oleh seorang yang belum dikenal identitasnya. Bom tersebut menewaskan sekitar 5 orang. Setelah ditelusuri oleh aparat setempat, bom tersebut berhubungan dengan Boko Haram dan ISIS di Chad, Afrika. ${ }^{32}$

Dari sejumlah data di atas dapat disimpulkan bahwa kasus-kasus intoleransi yang terjadi selama ini sangat erat kaitannya dengan latar belakang perbedaan pemahaman dalam beragama. Hal ini juga memungkinkan kasus-kasus intoleransi dapat terus meningkat atau justru bertambah di tiap kurun tahunnya. Dengan kemungkinan tersebut, tentunya dapat diupayakan berbagai cara

${ }^{29}$ Diakses dari https://www.bbc.com/indonesia/indonesia-47801818 pada 12 Agustus 2019.

30 "Kasus Intoleransi sepanjang 2018" dalam https:// www.idntimes.com ,diakses pada 14 Agustus 2019.

31 "Kasus Intoleransi sepanjang 2018” https:// wmw.idntimes.com, diakses pada 14 Agustus 2019.

32 "Bom Bunuh Diri di Chad, 5 orang Tewas" dalam bttps:// m.detik.com diakses pada 14 Agustus 2019. 
untuk mewujudkan kehidupan manusia yang damai dan tidak merugikan berbagai pihak. Atas dasar hal itu, penulis mencoba menggunakan Tawbidic Paradigm sebagai salah satu upaya untuk mewujudkan masyarakat yang lebih moderat dan toleran, sebagaimana yang telah disebutkan di atas sebelumnya.

\section{Tawhidic Paradigm Sebagai Tawaran mewujudkan Toleransi antar Umat Beragama}

Pada sub bab sebelumnya telah ditampilkan beberapa tokoh yang menjadikan tauhid sebagai basis pemikirannya misalnya seperti Amina Wadud, Farid Essack dan Abdurrahman Wahid. Para tokoh tersebut mencoba merekonstruksi pemahaman konsep tauhid dan cara kerjanya sehingga tauhid dapat menjadi basis keadilan, humanism, bahkan pembebasan. Oleh karena itu dalam pembahasan kali ini merupakan tawaran yang ingin berikan terkait dengan bagaimana mengubah paradigma tauhid menjadi sebuah basis toleransi dalam beragama.

Sebagaimana di bagian awal, tulisan ini menyinggung bagaimana perkembangan tauhid yang pada awalnya merupakan konsep teoritis hingga menuju konsep praksis yang dapat menyelesaikan realitas kehidupan manusia, dalam hal ini khususnya problematika intoleransi dalam umat beragama. Untuk menjadi sebuah solusi tawaran tentu saja membutuhkan tahapan-tahapan agar konsep yang ingin disampaikan menjadi jelas. Oleh karena itu dalam hal ini ada beberapa tahapan yang perlu ditempuh agar paradigma tauhid ini menjadi basis toleransi antar umat beragama, di antaranya ialah:

1. Memahami Secara Utuh Konsep Tauhid

Sebagaimana telah disinggung pada bagian awal bahwasannya seiring berkembangnya zaman tauhid terus mengalami pemtangan konsep mulai dari ranah teoritis hingga ke ranah praksis, dari isu-isu melangit hingga isu-isu yang sangat erat kaitannya dengan realitas manusia, dari nalar teosentris hingga ke antroposentris.

Pemahaman-pemahaman seperti ini jarang sekali dipahami oleh masyarakat awam sehingga menimbulkan kesalahpahaman dalam beragama dan menyebabkan munculnya gerkan-gerakan yang seakan-akan membela tuhan dengan mengatasnamakan jibad fi sabilillah namun faktanya malah merusak kemaslahatan yang lebih besar.

Oleh karena itu tahapan awal yang harus ditempuh agar terwujudnya toleransi antar umat beragama ialah menanamkan kesadaran untuk memahami konsep tauhid dan apa maqashid yang ingin disampaikan oleh konsep tauhid itu sendiri. Sehingga dengan memahami hal ini tentu saja seseorang akan lebih menyadari apa sebenarnya tujuan dasar tauhid itu sendiri.

2. Visi Kalimatun Sawa Dalam Umat Beragama

Dalam prespektif paradigma antroposentris beragama masuk dalam kategori al-haqq al-larim. Karena dirinya sendiri seseorang mempunyai hak beragama, juga berhak memilih menggunakan haknya atau tidak. Ketika orang tersebut telah menentukan pilihannya, maka orang lain tidak boleh ikut campur, selain menghormatinya. 
Karena beragama masuk ke dalam kategori al-haqq al-lazim, maka kebebasan beragama bersifat mutlak. Kemutlakan kebebasan beragama tidak hanya dalam lingkup hak asasi manusia, tetapi hal ini juga dalam kerangka al-Quran yang menegaskan dilarang adanya paksaan dalam beragama. ${ }^{33}$

Dengan kerangka seperti ini sejatinya hak seseorang dalam beragama tentu saja tidak boleh dibatasi oleh suatu hal yang bersifat eksternal atau dengan kata lain orang yang beragama berhak mengekspresikan ekspresi keaagamaannya. ${ }^{34}$ Oleh karena itu yang menjadi batasan dalam beragama ialah sebenarnya individu itu sendiri. Hal ini dikarenakan individu tersebut bagian dari masyarakat, maka dalam mengekspresikan hak asasinya ia harus mempertimbangkan hak orang lain, bukan orang lain yang berhak membatasinya, melainkan hanya sebatas menghargai ekspresiekspresi keberagamaan yang ada.

Ketika masing-masing pihak sudah saling mengetahui dan menghargai perbedaan keyakinan, kebenaran dan keselamaran agama masing-masing, maka perlu diadakan tindak lanjut kea rah yang lebih konkret yaitu kerjasama antar agama dalam hal-hal yang mempunyai kesamaan atau dalam bahasa al-Quran yaitu kalimatun sawa. Misalnya kerjasama memberantas kemiskinan, menjunjung tinggi hak asasi manusia, menolak kekerasan dalam bentuk apapun dan lain sebagainya. Sehingga dari kerja sama tersebut akan menciptakan kerukunan dan keharmonisan dalam kehidupan beragama. ${ }^{35}$

\section{Kesimpulan}

Intoleransi agama memiliki kemungkinan untuk meningkat atau justru bertambah di tiap kurun tahunnya. Dengan adanya kemungkinan tersebut, tentunya dapat diupayakan berbagai cara untuk mewujudkan kehidupan bermasyarakat yang lebih damai, moderat dan toleran seingga tidak merugikan pihak manapun, khususnya dalam mengekspresikan keberagaman dalam beragama. Atas dasar hal itu, penulis mencoba menggunakan Tawhidic Paradigm sebagai salah satu upaya untuk mewujudkan hal tersebut. Ketika masing-masing pihak sudah saling mengetahui dan menghargai perbedaan keyakinan, kebenaran dan keselamatan agama masing-masing, maka perlu diadakan tindak lanjut ke arah yang lebih konkret yaitu kerjasama antar agama dalam hal-hal yang mempunyai kesamaan atau dalam bahasa al-Quran yaitu kalimatun sawa. Misalnya kerjasama memberantas kemiskinan, menjunjung tinggi hak asasi manusia, menolak kekerasan dalam bentuk apapun dan lain sebagainya. Sehingga dari kerja sama tersebut akan menciptakan kerukunan dan keharmonisan dalam kehidupan beragama.

\section{Daftar Pustaka}

Abduh, Muhammad. 1992 Risalah Taubid, Jakarta: Bulan Bintang.

An-Nawawi. 2015. Tafsir Marah Labid, Beirut:Dar al-Kitab al-Ilmiyyah.

At-Thobari.2013. Jami' al-Bayan fi Ta'wil al-Qur'an. Beirut: Dar Ar-Risalah.

Azra, Azyumardi.2003 Hassan Hanafi dari Akidah ke Revolusi Sikap Kita Terbadap

Tradisi Lama. Jakarta: Paramadina.

Badruzman, Abad. 2005. Kiri Islam Hassan Hanafi Menggugat Kemapanan Agama dan

Politik. Yogyakarta: Tiara Wacana.

\footnotetext{
${ }^{33}$ Kementrian Agama Repubik Indonesia, Al-Qur'an dan Terjemahnya, 175.

${ }^{34}$ Aksin Wijaya, Dari Membela Tuban ke Membela Manusia, (Bandung: Al-Mizan, 2018),186.

${ }^{35}$ Aksin Wijaya, Dari Membela Tuban ke Membela Manusia, (Bandung: Al-Mizan, 2018), 187.
}

62 | Nuzul Firiansyah \& Rachma Vina Tsurayya - Tauhid Paradigm Sebagai Basis,.. 
Crashwell, Jhon. W. 2016. Research Design.terj. Achmad Fawaid dan Rianayati Kusmini. P. Yogyakarta: Pustaka Pelajar.

Esack, Farid. 1996. al-Qur'an, Pluralism and Liberation: An Islamic Perspective of Interreligious Solidarity Against Opression. New York: Oneworld.

Hanafi, Hassan. 2003. Dari Aqidah ke Revolusi, terj. Asep Usman Ismail (dkk), Jakarta: Paramadina.

Kementrian Agama Republik Indonesia. 2010. Al-Qur'an dan Terjemabnya. Kudus: Menara Kudus.

Kuntowijoyo. 2006. Islam Sebagai Ilmu Epistemologi, Metodologi, dan Etika. Yogyakarta: Tiara Wacana.

Laporan Siaran Pers Setara Institute "Melawan Intoleransi di Tahun Politik; Kondisi

Kebebasan Beragama/Berkeyakinan dan Pemajuan Toleransi di Indonesia Tahun 2018”.

Mulia, Siti Musdah "Menuju Kebebasan Beragama di Indonesia" dalam Hakim, ed.

Bayang-bayang Fanatisme: Esai-esai untuk mengenang Nur Cholish.

Munawir. 2016. 'Fenomena Bencana Dalam Al-Qur'an Perspektif Pergeseran Teologi dari Teosentris ke Antroposentris". Jurnal Maghza Institut Agama Islam Negeri Purwokerto.

Munir, Ghozali. 2013. Taubid Sejarah dan Implementasi. Semarang: Rasail Media Grup.

Mustofa, Agus. 2008. Mengubah Takdir Serial ke-7 Diskusi Tasawuf Modern, Surabaya: PADMA Press.

Nasir, Sahilun A. 2012. Pemikiran Kalam (Teologi Islam) Sejarah Agama dan Perkembangannya. Jakarta: PT. Raja Grafindo Persada.

Nasution, Harun. 1986. Teologi Islam Aliran-Aliran Sejarah Analisa Perbandingan. Jakarta: UI Press.

Resolusi Majlis Umum Ratifikasi dan Aksesi Konvenan Internasional Hak-hak Sipil dan

Politik. Diakses dari Lembaga Studi dan Advokasi Masyarakat dalam bttps:// referensi.elsam.or.id/2014/09/konvenan-internasional-bak-bak-sipil-dan-politik// pada 14 Agustus 2019.

Setara Institute, "Melawan Intoleransi di Tahun Politik; Kondisi Kebebasan

Beragama/Berkeyakinan dan Pemajuan Toleransi di Indonesia Tahun 2018”.

The Wahid Foundation. 2018. Laporan Tahunan Kemerdekaan Beragama/Berkeyakinan (KBB) di Indonesia 2017. Jakarta: Wahid Foundation.

Wadud, Amina. 1999. Qur'an and Woman: Rereading the Sacred Text from a Woman's Perspective.New York: Oxford University Press.

Wahid, Abdurrahman. "Tafsir Surat Al-Baqarah:256 tentang Saling Menghormati" .btps:// islami.co/ diakses pada 15 Agustus 2019.

Wijaya, Aksin. 2018. Dari Membela Tuhan ke Membela Manusia. Bandung: Mizan.

Zainuddin. 1996. Ilmu Taubid Lengkap. Jakarta: Rineka Cipta.

Sumber Lain:

https://m.detik.com

bttps://islami.col

https:// www.bbc.com/indonesia/indonesia-47801818

https://wnw.idntimes.com

bttps:// wmw.gusdurian.net// diakses pada 15 Agustus 